\title{
Verb-final conjunct clauses in Old English prose
}

\section{The role of Latin in translated texts}

\author{
Anna Cichosz \\ University of Lodz
}

The aim of this study is to analyse intertextual differences in the use of Vfinal order in Old English conjunct clauses and to determine to what extent the source of these differences may be Latin influence. The analysis reveals that the frequency of $\mathrm{V}$-final order in $\mathrm{OE}$ conjuncts is rather limited in most texts, and Bede's Historia Ecclesiastica surfaces as the text in which the frequency of $\mathrm{V}$-final conjunct clauses is exceptionally high. The study shows that the regular use of $\mathrm{V}$-final order in Bede may be interpreted as a translation effect, with Latin inflating the frequency of the pattern in conjunct clauses, which means that the frequency of $\mathrm{V}$-final conjunct clauses in early OE translations may not reflect native tendencies.

\section{Conjunct clauses and the verb-final order}

Old English conjunct clauses, i.e. main declarative clauses introduced by coordinating conjunctions, mainly and 'and' and $a c$ 'but', are often claimed to be verbfinal (Mitchell 1985: § 1685; Traugott 1992: 277; Fischer et al. 2000:53; Ringe \& Taylor 2015: 419) as in (1).

(1) and pær nænig mann for wintres cyle on sumera heg ne mawep and there no man for winter's cold on summer hay not mows

'And there no one mows hay in the summer against winter's cold'

(cobede, Bede_1:1.28.32.219)

Nonetheless, the tendency for conjunct clauses to follow the V-final order is usually presented in a rather imprecise way. In Fischer et al. (2000), the authors say:

Although a small number of main clauses have no Verb-Second (Koopman 1995), the number of coordinate main clauses lacking it is far greater (even ones starting 
with a topic) and they often have the verb-final orders usually associated with subordinate clauses.

(Fischer et al. 2000:53, emphasis mine)

According to Fischer et al. (2000:53), "failure to recognise it [conjunct clauses] as a separate category yields a very misleading picture of main clause word order". In numerous other studies these claims are formulated in the same way:

It is a traditional observation that conjunct clauses in Old English behave more like subordinate clauses than main clauses (e.g. with respect to word order) (Traugott 1972, Mitchell 1985, Kemenade 1987). In particular, second conjuncts of conjoined main clauses are more frequently verb-final than other main clauses.

(Fuß \& Trips 2002: 209, emphasis mine)

It has often been observed in the literature that conjoined main clauses seem to favour subordinate clause word order in OE.

(Haeberli 2002: 224, emphasis mine)

The Subject... Verb word-order is commonly found in subordinate clauses and clauses introduced by and/ond and $a c$.

(Baker 2012:118, emphasis mine)

In her recent article, Bech (2017) shows that the tendency of conjunct clauses to follow the V-final order is not confirmed by corpus data since "conjunct clauses are more frequently verb-final than main clauses are, but that is different from saying that they are frequently verb-final" (Bech 2017:5). Her analysis, based on the York-Toronto-Helsinki Parsed Corpus of Old English Prose (YCOE) (Taylor et al. 2003), reveals that only $11 \%$ of OE conjunct clauses are V-final, i.e. they have the finite verb in the absolute clause-final position, with some element(s) intervening between the subject and the verb. According to Bech (2001, 2017), the higher frequency of the V-final order in conjunct clauses is a by-product of their function in OE discourse and not a special structural feature of this clause type. This interpretation is questioned by Zimmermann (2017), who claims that OE coordinating conjunctions would sometimes behave like complementisers in subordinate clauses, blocking the $\mathrm{C}$ position and leading to the clause-final placement of the verb, though "conjunctions are not necessarily inserted under $\mathrm{C}$ but may be logical connectors instead" (Zimmermann 2017:171), which is interpreted as the reason for the less frequent (non-categorical) appearance of the finite verb in the clause-final position in conjunct clauses, as opposed to subordinates. What is more, Zimmermann (2017) shows that the variation is related to diachrony: Vfinal conjunct clauses are more frequent in early OE texts.

According to Mitchell (1985: $\S 3911$ ), the S...V order, which is "sometimes called 'subordinate' - is common in clauses introduced by ond, ac, or conj. $n e$... and in subordinate clauses", and for an unambiguous example of this pattern the 
intervening element placed between the subject and the verb must be a nominal object, a nominal or adjectival complement or a participle or infinitive which is a part of a complex verb phrase, as in (2)-(4).

(2) And hi his fet cystun and they his feet kissed 'And they kissed his feet'

(coaelive, ÆLL_[Vincent]:222.7942)

(3) ond his clænnes swiðe mære wæs and his purity very great was 'And his purity was great' (comart3, Mart_5_[Kotzor]:Ja24, A.11.239)

(4) and se deað siððan us derian ne mæg and the death later us hurt not may

'And then death cannot hurt us' (cocathom2,ÆCHom_II,_12.2:122.434.2686)

It is important to note that S...V automatically excludes clauses without an overt subject and since in conjunct clauses subjects are often unexpressed, focusing on clauses with overt subjects only may influence the results of a quantitative study. According to Pintzuk (1999, 2005 quoted in Ringe \& Taylor 2015: 406), any clause with at least two heavy pre-verbal constituents is considered V-final, which suggests that clauses without overt subjects could also be counted as such. Nonetheless, according to Ringe \& Taylor (2015:406), the only clear diagnostic for the V-final structure is the order lexical verb - auxiliary verb as in (4), and the identification of the V-final order in clauses without a complex verb phrase is "more difficult".

All in all, it seems that one of the difficulties in assessing the actual frequency of the V-final order in conjunct clauses is the way in which the term "V-final" is interpreted by scholars working within different theoretical frameworks. Traditional studies, discussed in Bech (2017), where the relation between the presence of a coordinating conjunction and the use of the V-final order was first noted, looked at surface structure only and used the broad and intuitive definition of $\mathrm{V}$ final as a clause with the finite verb at the very end, without any additional rules. Let us consider the order of a set of conjunct clauses in (5)-(8).

(5) and mid geornfulre elnunge up arisende wæs and with eager zeal up rising was 'And he was rising up eagerly' (coaelive, ÆLS_[Martin]:247.6125) In (5) we can see a clause with the finite verb at the end, but without an overt subject. Such a clause would not be counted as V-final by Mitchell (1985). Nor would it by Bech (2017), who follows Mitchell's (1985) definition of S...V as the basis for her investigation. However, some elements used in the clause are clearly heavy 
and the finite verb follows the non-finite form, so for Ringe \& Taylor (2015) and Pintzuk $(1999,2005)$ the clause would count as V-final.

(6) \& his leorningcnihtas him fyligdon and his disciples him followed 'And his disciples followed him' (cowsgosp, Lk_[WSCp]:22.39.5476)

(7) Ac ic cann hine but I can him 'But I know him' (cocathom2,ÆCHom_II,_13:128.35.2802)

In (6) we can see a clause with an overt subject and a clause-final verb, with a pronominal object placed in between. Bech (2017) includes such clauses in her initial calculation but excludes them at the next stage of her analysis in order to assess Mitchell's (1985) claims because in his study such clauses do not count as V-final. Nonetheless, it is possible to have an alternative order as in (7), so even though OE personal pronouns show a strong tendency for the preverbal placement, it is not a categorical rule and one may wonder whether (6) and (7) are equally strong non-V-final clauses.

Moreover, in studies of OE syntax written within the generative framework, many clauses which are not $\mathrm{V}$-final on the surface are interpreted as such because of a number of processes which may change their underlying order. The analysis of these phenomena is usually restricted to subordinate clauses, where the V-final order is predominant, but if we assume that $\mathrm{OE}$ coordinating conjunctions sometimes behave like complementisers (as suggested by Zimmermann 2017), these interpretations may be transferred to conjunct clauses.

(8) Ac ðæra synna forgyfenyss stent on pam Halgan Gaste but the sins-GEN forgiveness stands on the Holy Ghost 'But the forgiveness of the sins depends on the Holy Ghost'

(coaelhom,æHom_6:250.997)

One of the most productive processes modifying the original V-final order would be extraposition, which moves a (heavy) constituent, very often a prepositional phrase, to the right of the verb. This means that one of the structural interpretations of the underlying order of (8) could be V-final (or OV), and a subordinate clause following such an order would not be treated as non-V-final. Nonetheless, in descriptive studies such as Mitchell (1985) or Bech (2017) such clauses are never counted as V-final; they are treated rather as typical SVX main clauses. Another important process to mention in this context is verb-raising (van Kemenade 1987) illustrated in (9) and verb-projection raising (Pintzuk 1996) shown in (10), where the finite form is placed before the non-finite form (and before the object of the lexical verb, if it is expressed). 
(9) \& him pis word wæs behydd and him this word was hidden

'And the word was hidden from him'

(cowsgosp, Lk_[WSCp]:18.34.5160)

(10) ac we wyllað eow secgan

but we will you say

'But we want to tell you'

(coaelhom,ÆHom_19:60.2703)

Such clauses would also be classified as V-final by a generative linguist, while a descriptive study would treat them differently (as XSV and SVX respectively). In this context, it is interesting to note that while the order lexical verb - auxiliary is treated as the only firm diagnostic of the $\mathrm{V}$-final order, the opposite ordering is not a diagnostic for a $\mathrm{V}$-initial structure but rather a possible variant of the $\mathrm{V}$-final pattern. The processes of verb-raising and verb-projection raising are optional in OE subordinate clauses and the choice was shown to depend on date of composition, text and type of the finite verb (Haeberli \& Pintzuk 2012).

All in all, it seems that the strength of the V-final tendency in OE conjunct clauses heavily depends on the definition of V-final order. This study, which aims to investigate the intertextual variation of $\mathrm{OE}$ prose texts with respect to the use of $\mathrm{V}$-final order in conjunct clauses, uses different definitions of V-final in order to show how particular texts differ from one another, and one of the variables which is taken into account is translation status.

The influence of Latin on OE word and constituent order is often downplayed and translations are treated as syntactically independent compositions even though there are studies that show how certain patterns are influenced by the source text order (Cichosz et al. 2016; Cichosz 2017; Ohkado 200o). Pintzuk \& Haeberli (2008:396) decided not to take the influence of Latin into account when investigating the frequency of $\mathrm{V}$-final structures in $\mathrm{OE}$ main clauses, though at the same time they admit that "it is interesting and may be relevant" that two clauses used as the basis for some part of their discussion come from translations, Orosius and the West-Saxon Gospels (Pintzuk \& Haeberli 2008: 406, note 14). According to Zimmermann (2017:118) "The distributional differences between MCs [main clauses] and CCs [conjunct clauses] are unlikely to be due to Latin interference effects since they appear in both translated as well as original prose..." This approach is questioned in this study, which shows how Latin may have influenced the frequency of $\mathrm{V}$-final order in $\mathrm{OE}$ translated texts based on the example of Bede's Historia Ecclesiastica. 


\section{Methodology}

The data for the study were acquired from the York-Toronto-Helsinki Parsed Corpus of Old English Prose (Taylor et al. 2003) searched by means of the CorpusSearch 2 application (Randall et al. 2005-2013). In order to assess the proportion of V-final clauses among all OE conjunct clauses, first all conjunct clauses were extracted from the corpus. A conjunct clause was defined as a main clause with a coordinating conjunction (CONJ) in the clause-initial position and an indicative verb (Query 1). ${ }^{1} \mathrm{~V}$-final clauses were defined in three ways:

a. broad V-final

These are conjunct clauses with the verb in the clause-final position, regardless of all the other clause elements (Query 2). This includes short clauses consisting of the conjunction and the verb only, clauses with null subjects and clauses with light intervening phrases.

b. S...V

The query is a modified version of Bech's (2017) query for V-final conjunct clauses (Query 3). It is a clause with a coordinating conjunction in the clause-initial position, an overt subject, a finite verb form in the clause-final position and another constituent (adverb, adjective, prepositional phrase, non-finite verb or a noun phrase in the accusative or dative case) placed between the subject and the verb. Negative particles are not taken into account in the calculations (some clauses rendered by Bech's (2017) query had only the negative particle ne placed between the subject and the verb).

c. strict V-final (lexical verb - auxiliary verb)

The strictest definition of $\mathrm{V}$-final involves only clauses with complex verb phrases (Query 4). The proportion of V-final clauses is calculated on the basis of Query 5 , which requires the finite form to be the constituent immediately following the non-finite form.

In order to compare the proportion of V-final clauses with non-conjunct main clauses and subordinate clauses, a similar set of calculations was performed for the former (Queries 6-10) and latter group (Queries 11-15).

All the calculations are provided for the whole YCOE corpus and for the longest texts individually. The texts considered in the study of intertextual variation include those with at least 500 conjunct clauses (only the E manuscript of the

1. This excludes verbs in the imperative and subjunctive mood; ambiguous verbs were included in the calculations. 
Anglo-Saxon Chronicle is taken into account since it contains the largest number of conjunct clauses, only the $\mathrm{C}$ version of Gregory's Dialogues is included because it contains more conjunct clauses than the $\mathrm{H}$ version).

Since we have no comprehensive parallel corpora of $\mathrm{OE}$ translations and their source texts, the analysis of the relations between the source and the target text of Bede (Section 4) had to be manual, i.e. the source clauses for the OE S...V clauses were identified in the Latin text manually and aligned to their OE equivalents. Then, the Latin clauses were analysed and divided into V-final and non-V-final. If it was impossible to find a specific equivalent of the OE clause in the Latin source text, or if the clause was a major structural paraphrase of the source, it was classified as a free translation (examples are shown in relevant fragments of Section 4). Since the exact Latin manuscript which served as the source for the anonymous OE translator is unknown (Lemke 2015:43) and it has probably not survived (Wallis 2013), the Latin edition was chosen on the basis of its availability in the electronic form (Plummer 1896).

\section{Intertextual differences}

Table 1 shows the first part of the data extracted from the YCOE corpus. The number of V-final clauses is based on the broad definition of a V-final clause, i.e. a clause with a finite verb at the end, with no additional requirements.

Table 1. The frequency of broad V-final clauses in individual texts from YCOE

\begin{tabular}{|c|c|c|c|c|c|c|c|c|}
\hline & \multirow[b]{2}{*}{ Subperiod } & \multirow[b]{2}{*}{ Translation } & \multicolumn{2}{|c|}{ Conjunct } & \multicolumn{2}{|c|}{ Main } & \multicolumn{2}{|c|}{ Subordinate } \\
\hline & & & V-final & Total & V-final & Total & V-final & Total \\
\hline AS Chronicle E & early/late & no & $\begin{array}{c}486 \\
(21.1 \%)\end{array}$ & 2,305 & $\begin{array}{c}86 \\
(6.9 \%)\end{array}$ & 1,252 & $\begin{array}{c}542 \\
(42.8 \%)\end{array}$ & 1,267 \\
\hline $\begin{array}{l}\text { Ælfric’s Supp. } \\
\text { Homilies }\end{array}$ & late & no & $\begin{array}{c}174 \\
(9.4 \%)\end{array}$ & 1,850 & $\begin{array}{c}58 \\
(2.7 \%)\end{array}$ & 2,142 & $\begin{array}{c}1,105 \\
(32.3 \%)\end{array}$ & 3,420 \\
\hline Bede & early & yes & $\begin{array}{c}719 \\
(34.6 \%)\end{array}$ & 2,079 & $\begin{array}{c}221 \\
(8.3 \%)\end{array}$ & 2,648 & $\begin{array}{c}2,107 \\
(50.4 \%)\end{array}$ & 4,182 \\
\hline Blicking Homilies & early & no & $\begin{array}{c}270 \\
(21.0 \%)\end{array}$ & 1,286 & $\begin{array}{c}95 \\
(6.6 \%)\end{array}$ & 1,440 & $\begin{array}{c}848 \\
(40.4 \%)\end{array}$ & 2,100 \\
\hline Boethius & early & yes & $\begin{array}{c}90 \\
(10.2 \%)\end{array}$ & 882 & $\begin{array}{c}60 \\
(3.1 \%)\end{array}$ & 1,932 & $\begin{array}{c}1,273 \\
(39.0 \%)\end{array}$ & 3,265 \\
\hline
\end{tabular}


Table 1. (continued)

\begin{tabular}{|c|c|c|c|c|c|c|c|c|}
\hline & \multirow[b]{2}{*}{ Subperiod } & \multirow[b]{2}{*}{ Translation } & \multicolumn{2}{|c|}{ Conjunct } & \multicolumn{2}{|c|}{ Main } & \multicolumn{2}{|c|}{ Subordinate } \\
\hline & & & V-final & Total & V-final & Total & V-final & Total \\
\hline Catholic & late & no & 476 & 2,716 & 212 & 4,925 & 2,060 & 5,329 \\
\hline Homilies I & & & $(17.5 \%)$ & & $(4.3 \%)$ & & $(38.6 \%)$ & \\
\hline Catholic & late & no & 478 & 2,662 & 202 & 4,729 & 1,878 & 4,465 \\
\hline Homilies II & & & $(17.9 \%)$ & & $(4.3 \%)$ & & $(42.0 \%)$ & \\
\hline \multirow[t]{2}{*}{ Cura Pastoralis } & early & yes & 78 & 970 & 83 & 2,182 & 1,549 & 4,346 \\
\hline & & & $(8.0 \%)$ & & $(3.8 \%)$ & & $(35.6 \%)$ & \\
\hline Gregory's & early & yes & 332 & 2,605 & 121 & 2,698 & 1,472 & 5,420 \\
\hline Dialogues C & & & $(12.7 \%)$ & & $(4.5 \%)$ & & $(27.1 \%)$ & \\
\hline \multirow[t]{2}{*}{ Heptateuch } & late & yes & 229 & 2,491 & 133 & 2,592 & 1,003 & 2,589 \\
\hline & & & $(9.2 \%)$ & & $(5.1 \%)$ & & $(38.7 \%)$ & \\
\hline \multirow[t]{2}{*}{ Lives of Saints } & late & no & 401 & 3,621 & 108 & 4,079 & 1,527 & 4,671 \\
\hline & & & $(11.1 \%)$ & & $(2.6 \%)$ & & $(32.7 \%)$ & \\
\hline \multirow[t]{2}{*}{ Martyrology 3} & early & no & 90 & 1,034 & 17 & 1,134 & 289 & 1,020 \\
\hline & & & $(8.7 \%)$ & & $(1.5 \%)$ & & $(28.3 \%)$ & \\
\hline \multirow[t]{2}{*}{ Orosius } & early & yes & 367 & 1,587 & 94 & 1,615 & 1,309 & 2,947 \\
\hline & & & $(23.1 \%)$ & & $(5.8 \%)$ & & $(44.4 \%)$ & \\
\hline \multirow[t]{2}{*}{ Vercelli Homilies } & late & no & 239 & 1,124 & 101 & 1,421 & 914 & 2,197 \\
\hline & & & $(21.3 \%)$ & & $(7.1 \%)$ & & $(41.6 \%)$ & \\
\hline West Saxon & late & yes & 639 & 3,183 & 396 & 4,192 & 1,871 & 4,347 \\
\hline Gospels & & & $(20.1 \%)$ & & $(9.4 \%)$ & & $(43.0 \%)$ & \\
\hline \multirow[t]{2}{*}{ Wulfstan } & late & no & 77 & 774 & 29 & 575 & 586 & 1,442 \\
\hline & & & $(9.9 \%)$ & & $(5.0 \%)$ & & $(40.6 \%)$ & \\
\hline \multirow[t]{2}{*}{ YCOE } & - & - & 7,519 & 42,926 & 3,102 & 52,714 & 27,604 & 69,789 \\
\hline & & & $(17.5 \%)$ & & $(5.9 \%)$ & & $(39.5 \%)$ & \\
\hline
\end{tabular}

As can be seen from Table 1, even though the definition of V-final applied here is extremely simple and somewhat naïve, it shows the asymmetry between main and subordinate clauses quite well. There is no text in which the frequency of V-final main clauses exceeds 10\% (though in Bede and WS Gospels it gets close to this limit), and in 8 out of 15 texts considered in the study it does not reach 5\% (the average for the whole YCOE corpus is $5.9 \%$ ). By contrast, in subordinate clauses the proportion of the V-final pattern varies from $27-28 \%$ in Gregory C and Mar- 
tyrology 3 to $50 \%$ in Bede, with the corpus average at $39.5 \%$. Conjuncts are somewhere in between main and subordinate clauses, though the differences between individual texts are quite sharp: from $8-10 \%$ in Ælfric’s Supplemental Homilies, Boethius, Cura Pastoralis, the Heptateuch, Martyrology 3 and Wulfstan up to ca. $35 \%$ in Bede. It is clear that Bede's Historia Ecclesiastica is the most V-final OE long prose text, and it is true not only for conjunct clauses but pertains also to the other two clause types. Figure 1 illustrates the variation.

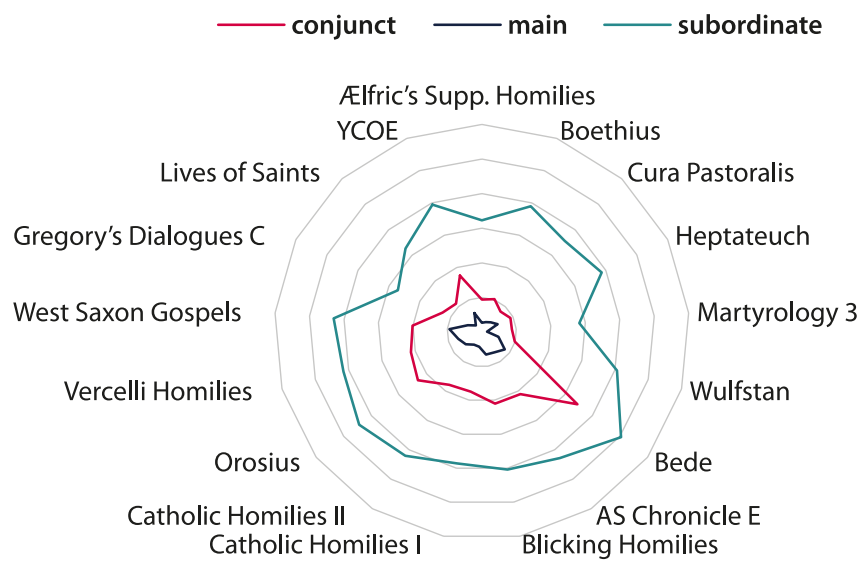

Figure 1. The proportion of V-final in main, conjunct and subordinate clauses in particular texts

While all the texts maintain a clear difference in frequency between the clause types, most of them show a more or less strong tendency to avoid the V-final order in main and conjunct clauses but use it very regularly in subordinate clauses. Bede, however, is an exception because this text shows a higher-than-average proportion of V-final clauses regardless of clause type, as illustrated in (11)-(13).

(11) Sume for hungre heora feondum on hand eodon some for hunger their enemies on hand went 'Some because of hunger gave themselves up into the hands of the enemies'

(cobede, Bede_1:12.54.2.493)

(12) \& Suðseaxna mægðe fram deofolgylda peawum to Cristes geleafan and South Saxon province from idols-GEN servants to Christ-GEN faith gecyrde;

converted

'And (he) converted the province of South Saxons from the worship of idols to the Christian faith'

(cobede, Bede_5:17.460.18.4626) 
(13) ðæt se ylca biscop an adliende mæden gebiddende gehælde that the same bishop a sick maiden praying healed 'That the same bishop healed a sick girl with his prayers'

(cobede, BedeHead:5.22.11.120)

When the texts are grouped according to the subperiod and translation status, as in Table 2, it turns out that early OE translations show the highest proportion of the $\mathrm{V}$-final order in conjunct clauses.

Table 2. Differences between the frequency of the V-final order between YCOE texts grouped according to subperiod and translation status

\begin{tabular}{lccc}
\hline & V-final conjuncts & Other conjuncts & Total \\
\hline early translations & $1,586(19.5 \%)$ & $6,537(80.5 \%)$ & 8,123 \\
late translations & $868(15.3 \%)$ & $4,806(84.7 \%)$ & 5,674 \\
all translations & $2,454(17.8 \%)$ & $11,343(82.2 \%)$ & 13,797 \\
early non-translations & $360(15.5 \%)$ & $1,960(84.5 \%)$ & 2,320 \\
late non-translations & $1,845(14.5 \%)$ & $10,902(85.5 \%)$ & 12,747 \\
all non-translations & $2,691(15.5 \%)$ & $14,681(84.5 \%)$ & 17,372 \\
\hline
\end{tabular}

* The total number for all non-translations is not a sum of early and late non-translations because it also includes Anglo-Saxon Chronicle E, which spans across both sub-periods.

The difference between the early and late translations is statistically significant, ${ }^{2}$ and so is the difference between translations and non-translations, ${ }^{3}$ but the difference between early and late non-translations is not. ${ }^{4}$ Thus, translation status is an important factor in the variation. Diachrony plays a role, but only for translated texts (which only partly confirms Zimmermann's (2017) results).

Naturally, the first definition of V-final applied to obtain the data is very broad and may not reveal the whole complexity of the situation. Therefore, I extracted another set of data from the YCOE corpus, this time focusing on S...V clauses only. The results are shown in Table 3 . The numbers are naturally lower, especially for conjunct clauses, where null subjects are used very regularly. Nonetheless, there are a few important observations to be made on the basis of these results. First of all, the difference between main and conjunct clauses is now much less sharp in some texts it is practically absent, as in Boethius and the Heptateuch. Next, the proportion of S...V in main clauses is virtually negligible in most texts; it exceeds

2. The chi-square statistic is 40.8172 . The $p$-value is $<.00001$

3. The chi-square statistic is 29.414 . The $p$-value is $<.00001$

4. The chi-square statistic is 1.7099 . The $p$-value is .190993 
Table 3. The frequency of S...V clauses in individual texts from YCOE

\begin{tabular}{|c|c|c|c|c|c|c|c|c|}
\hline & \multirow[b]{2}{*}{ Subperiod } & \multirow[b]{2}{*}{ Translation } & \multicolumn{2}{|c|}{ Conjunct } & \multicolumn{2}{|c|}{ Main } & \multicolumn{2}{|c|}{ Subordinate } \\
\hline & & & S...V & Total & S...V & Total & S...V & Total \\
\hline AS Chronicle E & early/late & no & $\begin{array}{c}162 \\
(7.0 \%)\end{array}$ & 2,305 & $\begin{array}{c}23 \\
(1.8 \%)\end{array}$ & 1,252 & $\begin{array}{c}431 \\
(34.0 \%)\end{array}$ & 1,267 \\
\hline $\begin{array}{l}\text { Ælfric’s Supp. } \\
\text { Homilies }\end{array}$ & late & no & $\begin{array}{c}63 \\
(3.4 \%)\end{array}$ & 1,850 & $\begin{array}{c}30 \\
(1.4 \%)\end{array}$ & 2,142 & $\begin{array}{c}772 \\
(22.6 \%)\end{array}$ & 3,420 \\
\hline Bede & early & yes & $\begin{array}{c}294 \\
(14.1 \%)\end{array}$ & 2,079 & $\begin{array}{c}160 \\
(6.0 \%)\end{array}$ & 2,648 & $\begin{array}{c}1,597 \\
(38.2 \%)\end{array}$ & 4,182 \\
\hline Blicking Homilies & early & no & $\begin{array}{c}110 \\
(8.5 \%)\end{array}$ & 1,286 & $\begin{array}{c}76 \\
(5 \cdot 3 \%)\end{array}$ & 1,440 & $\begin{array}{c}661 \\
(31.5 \%)\end{array}$ & 2,100 \\
\hline Boethius & early & yes & $\begin{array}{c}14 \\
(1.6 \%)\end{array}$ & 882 & $\begin{array}{c}24 \\
(1.2 \%)\end{array}$ & 1,932 & $\begin{array}{c}879 \\
(26.9 \%)\end{array}$ & 3,265 \\
\hline $\begin{array}{l}\text { Catholic } \\
\text { Homilies I }\end{array}$ & late & no & $\begin{array}{c}155 \\
(5.7 \%)\end{array}$ & 2,716 & $\begin{array}{c}107 \\
(2.2 \%)\end{array}$ & 4,925 & $\begin{array}{c}1,471 \\
(27.6 \%)\end{array}$ & 5,329 \\
\hline $\begin{array}{l}\text { Catholic } \\
\text { Homilies II }\end{array}$ & late & no & $\begin{array}{c}145 \\
(5.4 \%)\end{array}$ & 2,662 & $\begin{array}{c}103 \\
(2.2 \%)\end{array}$ & 4,729 & $\begin{array}{c}1,366 \\
(30.6 \%)\end{array}$ & 4,465 \\
\hline Cura Pastoralis & early & yes & $\begin{array}{c}30 \\
(3.1 \%)\end{array}$ & 970 & $\begin{array}{c}35 \\
(1.6 \%)\end{array}$ & 2,182 & $\begin{array}{c}1,175 \\
(27.0 \%)\end{array}$ & 4,346 \\
\hline $\begin{array}{l}\text { Gregory's } \\
\text { Dialogues C }\end{array}$ & early & yes & $\begin{array}{c}115 \\
(4.4 \%)\end{array}$ & 2,605 & $\begin{array}{c}71 \\
(2.6 \%)\end{array}$ & 2,698 & $\begin{array}{c}1,092 \\
(20.1 \%)\end{array}$ & 5,420 \\
\hline Heptateuch & late & yes & $\begin{array}{c}62 \\
(2.5 \%)\end{array}$ & 2,491 & $\begin{array}{c}44 \\
(1.7 \%)\end{array}$ & 2,592 & $\begin{array}{c}620 \\
(23.9 \%)\end{array}$ & 2,589 \\
\hline Lives of Saints & late & no & $\begin{array}{c}138 \\
(3.8 \%)\end{array}$ & 3,621 & $\begin{array}{c}64 \\
(1.6 \%)\end{array}$ & 4,079 & $\begin{array}{c}1,049 \\
(22.4 \%)\end{array}$ & 4,671 \\
\hline Martyrology 3 & early & no & $\begin{array}{c}30 \\
(2.9 \%)\end{array}$ & 1,034 & $\begin{array}{c}6 \\
(0.5 \%)\end{array}$ & 1,134 & $\begin{array}{c}205 \\
(20.1 \%)\end{array}$ & 1,020 \\
\hline Orosius & early & yes & $\begin{array}{c}121 \\
(7.6 \%)\end{array}$ & 1,587 & $\begin{array}{c}66 \\
(4.1 \%)\end{array}$ & 1,615 & $\begin{array}{c}1,028 \\
(34.9 \%)\end{array}$ & 2,947 \\
\hline Vercelli Homilies & late & no & $\begin{array}{c}96 \\
(8.5 \%)\end{array}$ & 1,124 & $\begin{array}{c}73 \\
(5.1 \%)\end{array}$ & 1,421 & $\begin{array}{c}694 \\
(31.6 \%)\end{array}$ & 2,197 \\
\hline $\begin{array}{l}\text { West Saxon } \\
\text { Gospels }\end{array}$ & late & yes & $\begin{array}{c}198 \\
(6.2 \%)\end{array}$ & 3,183 & $\begin{array}{c}160 \\
(3.8 \%)\end{array}$ & 4,192 & $\begin{array}{c}1,028 \\
(23.6 \%)\end{array}$ & 4,347 \\
\hline Wulfstan & late & no & $\begin{array}{c}27 \\
(3.5 \%)\end{array}$ & 774 & $\begin{array}{c}8 \\
(1.4 \%)\end{array}$ & 575 & $\begin{array}{c}429 \\
(29.7 \%)\end{array}$ & 1,442 \\
\hline YCOE & - & - & $\begin{array}{l}2,606 \\
(6.1 \%)\end{array}$ & 42,926 & $\begin{array}{l}1,718 \\
(3.2 \%)\end{array}$ & 52,714 & $\begin{array}{c}19,782 \\
(28.3 \%)\end{array}$ & 69,789 \\
\hline
\end{tabular}


5\% only in Vercelli Homilies, Blickling Homilies and Bede. Moreover, there are 9 texts in which the proportion of S...V conjunct clauses is lower than $5 \%$, and in all of these texts the proportion of S...V subordinate clauses is lower than $30 \%$ (these are: Ælfric's Supplemental Homilies, Boethius, Cura Pastoralis, Gregory C, the Heptateuch, Lives of Saints, Martyrology 3 and Wulfstan). Therefore, it seems that the use of the S...V order in particular texts across different clause types may somehow be correlated and - again - Bede surfaces as the most V-final text in the corpus, showing the highest proportion of S...V in all three clause types (14.1\% for conjuncts, $6.0 \%$ for main and $38.2 \%$ for subordinate clauses). Figure 2 illustrates these differences, (14) is a relevant example of an S...V conjunct clause from Bede.

(14) \& heo eac on pam gefeohte purh Godes fultom sige onfengon and they also on the fight through God-GEN help victory claimed 'And they also claimed victory during the battle with God's help'

(cobede, Bede_1:12.54.14.506)

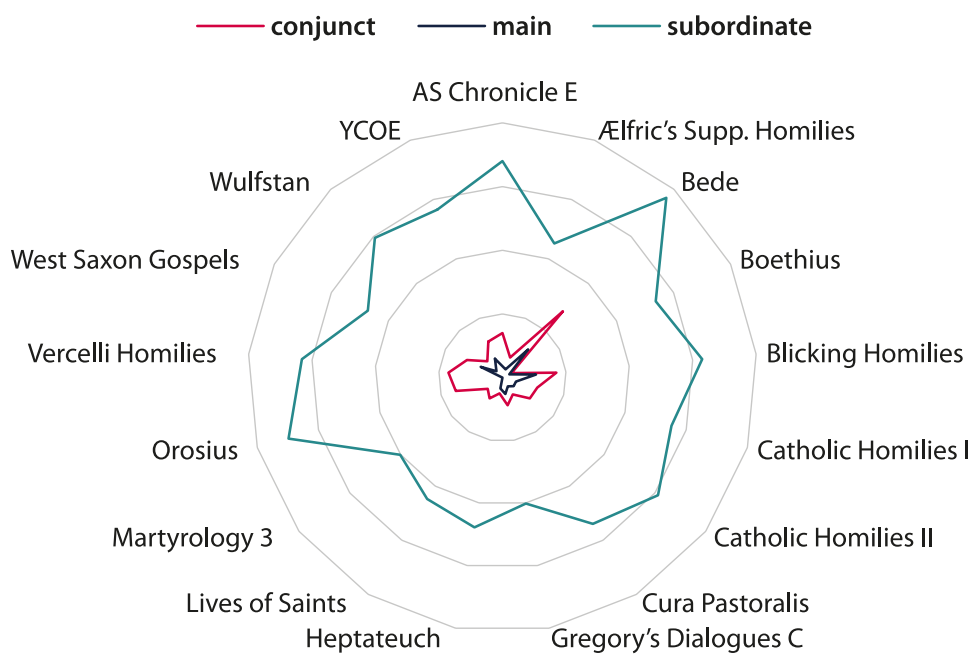

Figure 2. Proportion of S...V in main, conjunct and subordinate clauses in individual texts

When the texts are grouped (see Table 4) and the data are assessed by means of a statistical test, it turns out that (again) the difference between early and late translations is statistically significant, ${ }^{5}$ and so is the difference between trans-

5. The chi-square statistic is 36.2944 . The $p$-value is $<.00001$ 
lations vs. non-translations, ${ }^{6}$ while the difference between early and late nontranslations is not. ${ }^{7}$

Table 4. Differences between the frequency of the S...V order between YCOE texts grouped according to subperiod and translation status

\begin{tabular}{|c|c|c|c|}
\hline & S...V conjuncts & Other conjuncts & Total \\
\hline early translations & $574(7.1 \%)$ & $7,549(92.9 \%)$ & 8,123 \\
\hline late translations & $260(4.6 \%)$ & $5,414(95.4 \%)$ & 5,674 \\
\hline all translations & $834(6.0 \%)$ & $12,963(94.0 \%)$ & 13,797 \\
\hline early non-translations & $140(6.0 \%)$ & $2,180(94.0 \%)$ & 2,320 \\
\hline late non-translations & $624(4.9 \%)$ & $12,123(95.1 \%)$ & 12,747 \\
\hline all non-translations ${ }^{\star}$ & $926(5.3 \%)$ & $16,446(4.7 \%)$ & 17,372 \\
\hline
\end{tabular}

* The total number for all non-translation is not a sum of early and late non-translations because it also includes Anglo-Saxon Chronicle E, which spans across both sub-periods.

Naturally, the S...V pattern is also not a clear indicator of V-finality, as discussed in Section 1. Some of the conjunct clauses that counted as S...V are quite short and simple, as in (15), while others have a substantial number of long phrases placed before the clause-final verb as in (16).

(15) \& ic hine nime

and I him take

'And I take him'

(cowsgosp, Jn_[WSCp]:20.15.7408)

(16) ac he sona of wintra on pone winter eft cymeð

but he soon from winter on the winter again comes

'And he comes back from winter into winter' (cobede, Bede_2:10.136.2.1308)

Figure 3 shows the proportion between S...V conjunct clauses of varying length ${ }^{8}$ in the analysed texts (only texts with at least $100 \mathrm{~S} . . . \mathrm{V}$ conjunct clauses are included). It turns out that once again Bede stands out because S...V conjunct clauses from this particular text are very long: $75 \%$ of them contain at least seven words, while the corresponding result from the West Saxon Gospels is only 33\%. The general result for the whole YCOE is $55 \%$, but the differences between texts are again very substantial, and the proportion of long clauses in Bede is exceptionally high.

6. The chi-square statistic is 7.3658 . The $p$-value is .006648

7. The chi-square statistic is 5.2919. The $p$-value is .021425. The result is not significant at $p<.01$.

8. Extracted by means of DomsWords function in CorpusSearch2. 


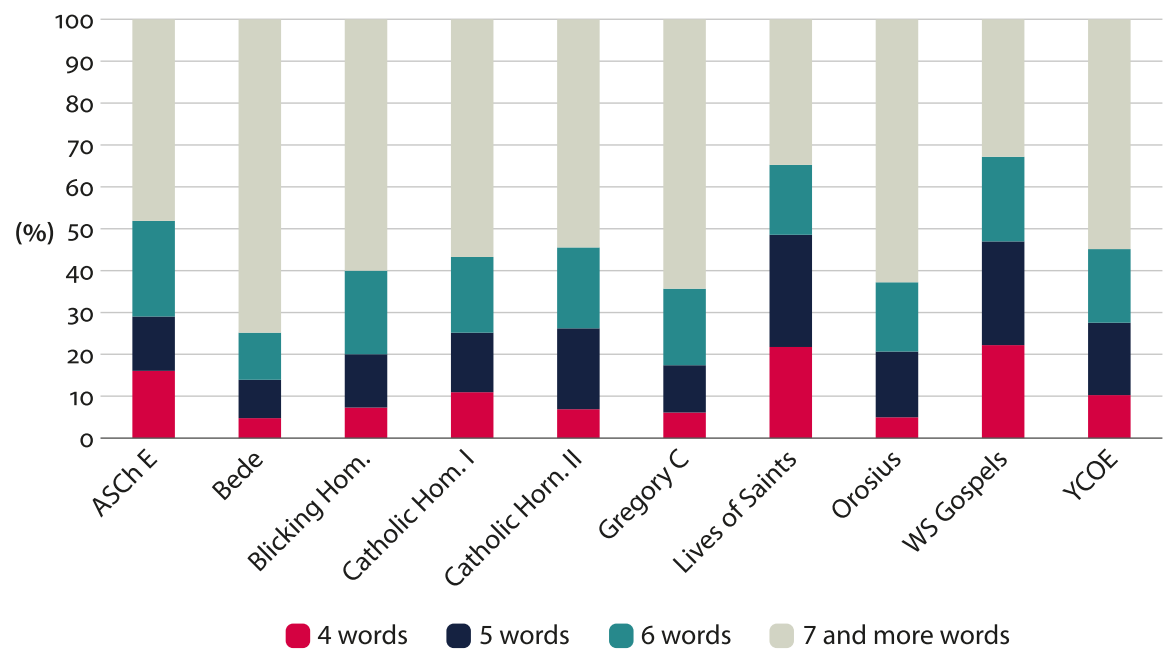

Figure 3. Proportions between S...V conjunct clauses of varying length in individual texts

Finally, I decided to use the strictest and most unambiguous definition of the $\mathrm{V}$-final structure and focused on clauses with a complex verb phrase only. Table 5 shows the number of all main, conjunct and subordinate clauses with a complex VP found in particular texts and the proportion of clauses in which the finite form follows the non-finite one.

Table 5. The frequency of V-Aux clauses in individual texts from YCOE

\begin{tabular}{|c|c|c|c|c|c|c|c|c|}
\hline & \multirow[b]{2}{*}{ Subperiod } & \multirow[b]{2}{*}{ Translation } & \multicolumn{2}{|c|}{ Conjunct } & \multicolumn{2}{|c|}{ Main } & \multicolumn{2}{|c|}{ Subordinate } \\
\hline & & & V-Aux & Total & V-Aux & Total & V-Aux & Total \\
\hline AS Chronicle E & early/late & no & $\begin{array}{c}17 \\
(10.2 \%)\end{array}$ & 166 & $\begin{array}{c}3 \\
(2.1 \%)\end{array}$ & 139 & $\begin{array}{c}106 \\
(33.5 \%)\end{array}$ & 316 \\
\hline $\begin{array}{l}\text { Ælfric’s Supp. } \\
\text { Homilies }\end{array}$ & late & no & $\begin{array}{c}13 \\
(5.3 \%)\end{array}$ & 244 & $\begin{array}{c}0 \\
(0 \%)\end{array}$ & 347 & $\begin{array}{c}152 \\
(25.7 \%)\end{array}$ & 592 \\
\hline Bede & early & yes & $\begin{array}{c}93 \\
(27.0 \%)\end{array}$ & 344 & $\begin{array}{c}29 \\
(5.8 \%)\end{array}$ & 495 & $\begin{array}{c}531 \\
(45.9 \%)\end{array}$ & 1,157 \\
\hline Blicking Homilies & early & no & $\begin{array}{c}23 \\
(10.3 \%)\end{array}$ & 224 & $\begin{array}{c}14 \\
(4.9 \%)\end{array}$ & 283 & $\begin{array}{c}204 \\
(39.6 \%)\end{array}$ & 515 \\
\hline Boethius & early & yes & $\begin{array}{c}3 \\
(1.8 \%)\end{array}$ & 166 & $\begin{array}{c}1 \\
(0.3 \%)\end{array}$ & 367 & $\begin{array}{c}237 \\
(33.7 \%)\end{array}$ & 704 \\
\hline
\end{tabular}


Table 5. (continued)

\begin{tabular}{|c|c|c|c|c|c|c|c|c|}
\hline & \multirow[b]{2}{*}{ Subperiod } & \multirow[b]{2}{*}{ Translation } & \multicolumn{2}{|c|}{ Conjunct } & \multicolumn{2}{|c|}{ Main } & \multicolumn{2}{|c|}{ Subordinate } \\
\hline & & & V-Aux & Total & V-Aux & Total & V-Aux & Total \\
\hline Catholic & late & no & 13 & 397 & 4 & 805 & 273 & 1,048 \\
\hline Homilies I & & & $(3.3 \%)$ & & $(0.5 \%)$ & & $(26.0 \%)$ & \\
\hline Catholic & late & no & 11 & 336 & 1 & 745 & 225 & 871 \\
\hline Homilies II & & & $(3.2 \%)$ & & $(0.1 \%)$ & & $(25.8 \%)$ & \\
\hline \multirow[t]{2}{*}{ Cura Pastoralis } & early & yes & 1 & 188 & 5 & 534 & 314 & 975 \\
\hline & & & $(0.5 \%)$ & & $(0.9 \%)$ & & $(32.2 \%)$ & \\
\hline Gregory's & early & yes & 19 & 457 & 5 & 509 & 296 & 1,246 \\
\hline Dialogues C & & & $(4.1 \%)$ & & $(1.0 \%)$ & & $(23.7 \%)$ & \\
\hline \multirow[t]{2}{*}{ Heptateuch } & late & yes & 3 & 122 & 3 & 194 & 127 & 369 \\
\hline & & & $(2.5 \%)$ & & $(1.5 \%)$ & & $(34.4 \%)$ & \\
\hline \multirow[t]{2}{*}{ Lives of Saints } & late & no & 13 & 388 & 4 & 642 & 236 & 971 \\
\hline & & & $(3.3 \%)$ & & $(0.6 \%)$ & & $(24.3 \%)$ & \\
\hline \multirow[t]{2}{*}{ Martyrology 3} & early & no & o & 115 & 0 & 105 & 13 & 226 \\
\hline & & & $(0 \%)$ & & $(0 \%)$ & & $(5.7 \%)$ & \\
\hline \multirow[t]{2}{*}{ Orosius } & early & yes & 56 & 187 & 15 & 251 & 355 & 695 \\
\hline & & & $(29.9 \%)$ & & $(5.9 \%)$ & & $(51.1 \%)$ & \\
\hline \multirow[t]{2}{*}{ Vercelli Homilies } & late & no & 14 & 181 & 7 & 247 & 215 & 550 \\
\hline & & & $(7.7 \%)$ & & $(2.8 \%)$ & & $(39.1 \%)$ & \\
\hline West Saxon & late & yes & 2 & 231 & 3 & 353 & 121 & 450 \\
\hline Gospels & & & $(0.9 \%)$ & & $(0.8 \%)$ & & $(26.9 \%)$ & \\
\hline \multirow[t]{2}{*}{ Wulfstan } & late & no & 3 & 137 & 1 & 90 & 123 & 300 \\
\hline & & & $(2.2 \%)$ & & $(1.1 \%)$ & & $(41.0 \%)$ & \\
\hline \multirow[t]{2}{*}{ YCOE } & - & - & 386 & 5,158 & 134 & 8,128 & 4,961 & 14,720 \\
\hline & & & $(7.5 \%)$ & & $(1.65 \%)$ & & $(33.7 \%)$ & \\
\hline
\end{tabular}

Quite expectedly, subordinate clauses use this order most frequently, though its frequency is close to $50 \%$ in only two texts: Bede and Orosius (and it is surprisingly low in Martyrology 3 ), see (17).

(17) Saga me hwæt sindon pa twegen fet pa peo sawul habban sceal tell me what are the two feet that the soul have shall 'Tell me what are the two feet that the soul should have' (coadrian, Ad:26.1.61) 
The use of the pattern in main clauses is very limited and in some texts it is not used at all, though in Bede and Orosius it is present in $6 \%$ of main clauses. (18) is one of the rare examples.

(18) Sona æfter pæm ealle heora peowas wið pa hlafordas winnende wæron soon after that all their servants against the lords winning were 'Soon afterwards all their servants were winning with the lords'

(coorosiu, Or_2:6.49.25.951)

When it comes to conjuncts, the intertextual differences are huge: from $0-2 \%$ in Wulfstan, Martyrology 3, Boethius, Cura Pastoralis and the West-Saxon Gospels to $30 \%$ in Orosius and $27 \%$ in Bede. In fact, 149 out of 386 such clauses present in YCOE (39\%) come from 2 texts: Bede and Orosius. Examples (19)-(22) and Figure 4 illustrate the variation.

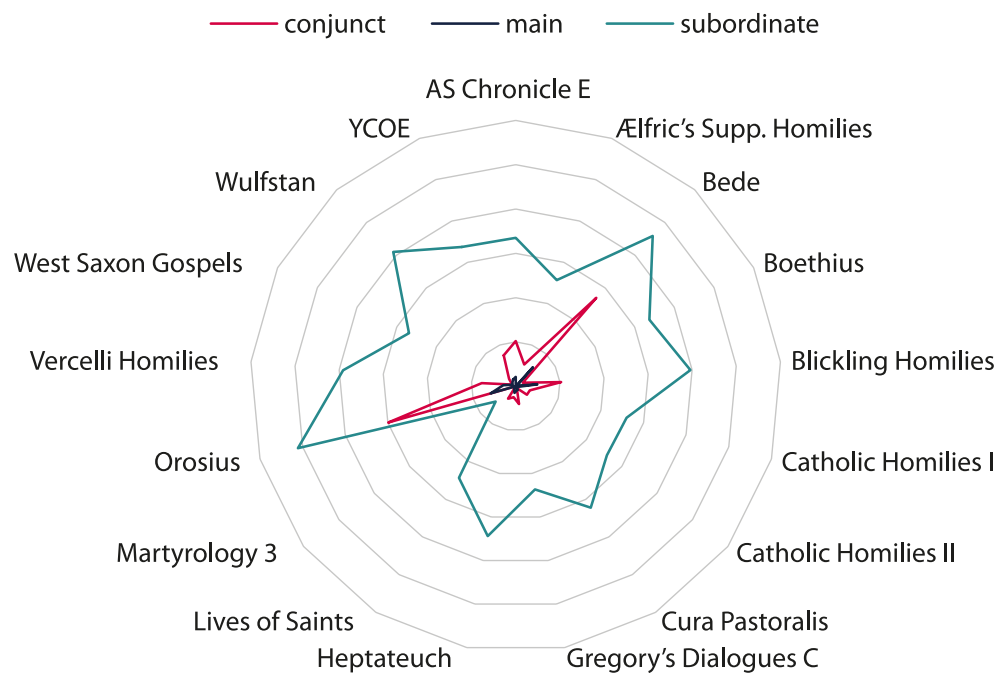

Figure 4. The proportion of the V-Aux pattern in main, conjunct and subordinate clauses with complex VPs in individual texts

(19) \& ic cristenum penungum ðeowian wylle

and I Christian services-DAT serve will

'And I want to serve Christianity'

(cobede, Bede_1:7.36.16.296)

(20) \& him Romane pæt swiðe ondrædende wæron and them Romans that very fearing were 'And the Romans were so afraid of them' (coorosiu, Or_2:4.41.12.780) 
(21) ond he mihte sona geseon and he might soon see 'And he soon may see' (comart3, Mart_5_[Kotzor]:Ja9, A.3.65)

(22) Ac we willað nu giet sprecan ymbe manna gecynd \& ymbe heora but we will now yet speak about men-GEN nature and about their tilunga endeavours

'But now we will yet speak about the nature of men and their endeavours' (coboeth, Bo:24.55.14.1006)

When the texts are grouped (Table 6), the difference between early and late translations turns out to be statistically significant, ${ }^{9}$ as is also the difference between early and late non-translations ${ }^{10}$ and translations vs. non-translations. ${ }^{11}$ The difference between early and late translations seems particularly striking: $13 \%$ vs. $1 \%$ of the strict V-final order.

Table 6. Differences between the frequency of the V-Aux order between YCOE texts grouped according to subperiod and translation status

\begin{tabular}{|c|c|c|c|}
\hline & V-Aux conjuncts & Aux-V conjuncts & Total \\
\hline early translations & $172(12.8 \%)$ & $1,170(87.2 \%)$ & 1,342 \\
\hline late translations & $5(1.4 \%)$ & $348(98.6 \%)$ & 353 \\
\hline all translations & $177(10.4 \%)$ & $1,518(89.6 \%)$ & 1,695 \\
\hline early non-translations & $23(6.8 \%)$ & $316(93.2 \%)$ & 339 \\
\hline late non-translations & $53(3.4 \%)$ & $1,502(96.6 \%)$ & 1,555 \\
\hline all non-translations ${ }^{\star}$ & $93(4.5 \%)$ & $1,967(95.5 \%)$ & 2,060 \\
\hline
\end{tabular}

* The total number for all non-translation is not a sum of early and late non-translations because it also includes Anglo-Saxon Chronicle E, which spans across both sub-periods.

Nonetheless, it is necessary to realise that early translations are not a consistent group, with Bede and Orosius on the one hand vs. Boethius, Cura Pastoralis and Gregory's Dialogues on the other, as shown in Table 7. The difference

9. The chi-square statistic is 38.8402 . The $p$-value is $<.00001$

10. The chi-square statistic is 8.2373 . The $p$-value is .004104

11. The chi-square statistic is 48.9648 . The $p$-value is $<.00001$ 
between Bede and Orosius vs. other early translations and vs. all other YCOE texts is statistically significant. ${ }^{12}$

Table 7. Bede and Orosius contrasted with other early OE translations and other YCOE texts

\begin{tabular}{lccc}
\hline & V-Aux conjuncts & Aux-V conjuncts & Total \\
\hline Bede \& Orosius & $149(28.1 \%)$ & $382(71.9 \%)$ & 531 \\
Boethius, Cura P and Gregory's Dialogues C & $23(2.8 \%)$ & $788(97.2 \%)$ & 811 \\
all YCOE without Bede \& Orosius & $237(5.1 \%)$ & $4,390(94.9 \%)$ & 4,627 \\
\hline
\end{tabular}

It seems that the use of V-Aux order in conjunct clauses is a text-specific feature which is not consistently dependent on either date of composition or translation status, and large-scale foreign transfer seems probable in two translated texts only: Bede and Orosius. Therefore, it seems that the YCOE texts should not be grouped according to sub-period because this may conceal the differences between individual compositions and produce an impression that the difference in the frequency of $\mathrm{V}$-final order in conjunct clauses is purely diachronic.

In short, the data extracted from the YCOE corpus show quite clearly that the $\mathrm{V}$-final order is, depending on the definition of $\mathrm{V}$-final, quite rare or very rare in conjunct clauses in most of the analysed texts. Nevertheless, there is one text, i.e. Bede's Historia Ecclesiastica, where its frequency is relatively high regardless of the definition, and the only other text which surfaced in the analysis (though its behaviour is less regular in this respect) is Orosius. Since both texts are translations, a translation effect would be the most obvious reason for their atypical syntactic behaviour. Moreover, Bede seems a more probable candidate for foreign transfer since it is generally claimed to be a close translation (Rowley 2015), and it has even been suggested that the Bede translator worked from a gloss of the Latin text (Brown 1969: 667; Bately 1988). Therefore, the next section will analyse the relations between the source and the target text order in Bede's Historia Ecclesiastica.

\section{Bede and translation effects}

As shown in Section 1, the potential influence of Latin on the syntax of OE translated texts is usually disregarded, and the use of the V-final order in OE conjunct

12. For Bede and Orosius vs. other early translations the chi-square statistic is 182.7218 and the $p$-value is $<.00001$, for Bede and Orosius vs. all other prose texts the chi-square statistic is 361.9967 and the $p$-value is $<.00001$. 
clauses is not an exception to this general approach (Pintzuk \& Haeberli 2008; Zimmermann 2017). Nonetheless, a careful examination of all the Latin source clauses for the $\mathrm{S} . . . \mathrm{V}^{13}$ conjuncts found in Bede reveals some interesting results presented in Table 8. It turns out that the majority of S...V conjunct clauses found in Bede have a clear Latin model as in (23)-(25).

Table 8. Relations between S...V conjuncts and their Latin source clauses in Bede

\begin{tabular}{lc}
\hline Relation to Latin & Proportion \\
\hline V-final into V-final & $192(65.3 \%)$ \\
non-V-final into V-final & $58(19.7 \%)$ \\
free translation & $44(15.0 \%)$ \\
Total & $\mathbf{2 9 4}$ \\
\hline
\end{tabular}

(23) a. et in processu epistulae ita suas calamitates explicant and in progress letter-GEN so their misfortunes explained

b. \& on forðgeonge pæs ærendgewrites pus hi heora yrmðo and on progress the-GEN letter-GEN thus they their misery arehton

presented

'And in the course of the letter thus they presented their misfortunes'

(cobede, Bede_1:10.48.5.423)

(24) a. atque ab Honorio archiepiscopo et rege Eadbaldo multum honorifice and by Honorius archbishop and king Eadbald very honourably susceptus est

received were

b. Ond hi from Honorie pæm ærcebiscope \& Eadbalde pam cyninge and they from Honorius the archbishop and Eadbald the king $<$ swiðe> arweorðlice onfongne wæron

very honourably received were

'And they were received with great honour by Archbishop Honorius and

King Eadbald'

(cobede, Bede_2:16.150.3.1437)

13. I have decided to analyse the degree of Latin influence for the second definition of V-final (modelled on Mitchell 1985 and Bech 2017) since even though it generally covers some short clauses with light intervening elements, virtually all of S...V conjunct clauses from Bede are relatively long and contain some heavy intervening phrases, as shown in Figure 3, so their V-finality is rather unambiguous. 
(25) a. qui libenter eum excipiens who gladly him receiving 'Who, receiving him gladly...'

b. Ond he lustlice hine onfeng and he gladly him received 'And he received him gladly'

(cobede, Bede_2:9.126.18.1196)

In most clauses classified as "V-final into V-final", the Latin source clause has a finite verb at the end as in (23a) and (24a). The target clauses are hardly ever wordfor-word copies since the translator regularly inserts subject pronouns into the target clauses as in (23b) and (24b), but the position of the verb and other clause constituents is the same. In (25) the situation is slightly different since the original clause is non-finite, but the verb is placed in the same position in the target clause, even though its form is changed. Such cases are also classified as "V-final into Vfinal", though their relation to the source text is less close.

In ca. $20 \%$ of the cases, the Latin source clause is not V-final and the translator moves the finite verb to the clause-final position without a clear trigger in the original text as in (26)-(28); the source clauses are mostly non-finite as in (26), and quite often they represent an absolute construction as in (27). However, there are also clauses such as (28), where the Latin shown in (28a) has a single phrase following the non-final verb, while the translator rearranged the order of these elements as in (28b).

(26) a. libenter auditus ab uniuersis

gladly heard by all

'Being gladly heard by everyone...'

b. \& he lustlice fram him eallum gehyred wæs

and he gladly by them all heard was

'And he was heard gladly by them all' (cobede, Bede_5:20.472.4.4744)

(27) a. et posito ibi signo

and placed-ABL there sign-ABL

'And with a sign placed there...'

b. Ond he pær tacen asette

'And he placed there a sign'

(cobede, Bede_3:7.178.33.1763)

(28) a. nemo propter hiemem aut faena secet aestate no one for winter either hay mows summer

'No one for the sake of winter in the summer either mows hay...' 
b. \& pær nænig mann for wintres cyle on sumera heg ne mawep and there no man for winter's cold on summer hay not mows 'And there no one mows hay in the summer against the winter's cold'

(cobede, Bede_1:1.28.32.219)

Finally, it was impossible to identify a clear source for the remaining $15 \%$ of S...V conjuncts since they come from heavily paraphrased fragments of the text.

All in all, it turns out that the frequent use of the S...V order in Bede may be treated as a translation effect since the proportion of clauses with a similar order in the source is very high. It is also interesting to note that translation effects may be observed even in clauses following the strictest definition of the V-final order, i.e. conjunct with a complex VP in which the finite form follows the non-finite one, as in (24), which means that the impact of Latin on the use of the V-final order must be taken into account regardless of the definition.

When we go back to the data from Table 4 and subtract the 192 clauses following the Latin order in Bede from the results for early translations (Table 9), the difference between early and late translations becomes statistically insignificant. ${ }^{14}$ Thus, the diachronic difference in the frequency of use of the V-final order (observed by Zimmermann 2017) is shaped by clauses which follow their source text order. Naturally, this could be interpreted as a syntactic coincidence (perhaps the order was so natural for early OE that following the source was more natural than rearranging the original constituent order), but such a high level of syntactic equivalence (65\%) cannot simply be ignored. In a similar study of V-initial main clauses in Bede only $21 \%$ of the clauses were found to follow the source text order closely (Cichosz 2017).

Table 9. Differences between the frequency of the S...V order between YCOE texts grouped according to subperiod and translation status, without calques from Bede

\begin{tabular}{llcc}
\hline & S...V conjuncts & other conjuncts & \multicolumn{1}{c}{ Total } \\
\hline early translations & $382(4.8 \%)$ & $7,549(95.2 \%)$ & 7,931 \\
late translations & $260(4.6 \%)$ & $5,414(95.4 \%)$ & 5,674 \\
all translations & $642(4.7 \%)$ & $12,963(95.3 \%)$ & 13,605 \\
\hline
\end{tabular}

Nonetheless, it would be unreasonable to explain all the uses of the V-final order in conjunct clauses from Bede on the basis of direct Latin influence. There are two possible and not necessarily exclusive interpretations of this fact: (a) the structure is native and the Latin model only increases its frequency, skewing the

14. The chi-square statistic is 0.4036 , the $p$-value is 0.525218 . 
quantitative part of the results but having no significant impact on the qualitative aspect, or (b) apart from direct translation effects, we are also dealing with an indirect influence of the source text on the target text. It does not seem reasonable to claim that the use of the S...V order in conjunct clauses in Bede is purely a syntactic calque, i.e. that the structure is not native to OE, because it is also present in other, non-translated texts. However, in other texts this order is usually a clear minority pattern and the fact that S...V conjunct clauses are so frequent in Bede may be interpreted as a combination of direct and indirect translation effects. Taylor (2008) divides the influence of the source text on the translated text into direct, when the translator reproduces the structure found in the source in the matching fragment of the target text, and indirect, when the translator "produces a higher frequency of a particular variant in the target, regardless of whether there is a matching structure in the source" (Taylor 2008:342). This effect is interpreted as a kind of syntactic priming and it is a probable mechanism in this particular case since the source text of Bede's Historia Ecclesiastica is dominated by V-final clauses (Cichosz et al. 2016:348). Thus, it is possible that the translator, exposed to the $\mathrm{V}$-final order to such an extent, was prone to reproduce this particular order in the target text even in places where the source text actually diverts from it. In short, the combination of direct and indirect translation effects would also explain the higher-than-average proportion of $\mathrm{V}$-final main and subordinate clauses in Bede, since in Latin V-final is the neutral order used for all clause types (Devine \& Stephens 2006), and the priming effect could apply to all syntactic contexts, inflating the frequency of $\mathrm{V}$-final in all the clauses from Bede.

\section{Conclusion}

This study confirms the results of recent corpus studies that V-final order in OE conjunct clauses is not as frequent as traditionally claimed (Bech 2017; Zimmermann 2017), and shows that there are substantial differences in the use of this order among particular OE prose texts. It turns out that, regardless of the definition applied, the only text in which V-final order is used regularly in conjunct clauses is Bede's Historia Ecclesiastica. What is more, the frequency of this pattern in Bede cannot be taken at face value since the text seems to have been heavily influenced by its Latin source, where the V-final order is regularly used.

These findings have some important consequences. First of all, studies that interpret the use of the V-final order in OE conjunct clauses should take translation effects into account since some of these clauses may not represent native contexts for the use of V-final order, and Bede may be just one of many translations that is influenced by a source text (a similar study is necessary to determine 
whether Orosius shows a similar degree of Latin influence). Next, it turns out that in many texts the constituent order difference between main and conjunct clauses is much less clear than generally suggested (e.g. in Fischer et al. 200o; Pintzuk \& Haeberli 2008; Zimmermann 2017). Thus, it may be worthwhile to reconsider whether conjunct clauses need to be treated as a third main clause type alongside main and subordinate clauses; perhaps they are just a subtype of main clauses with some (minor) syntactic peculiarities. Finally, the general approach of treating OE translations on a par with other prose texts as reliable sources for observations regarding OE syntax should be questioned (as signalled in Cichosz et al. 2016) since it turns out that translation effects may be an important factor underlying syntactic variation in OE prose. Still, more detailed studies on the impact of source texts on the use of particular syntactic structures are needed to assess the actual degree of this influence in particular translations and in OE translated prose in general.

\section{Funding}

The study was conducted as a part of the project "The variation of syntactic and phraseological constructions in Old English prose" (NCN research grant No. 2017/26/D/HS2/00272).

\section{References}

Baker, P. 2012. Introduction to Old English. London: Blackwell.

Bately, J. M. 1988. Old English prose before and during the reign of Alfred. Anglo-Saxon England 17. 93-138. https://doi.org/10.1017/S026367510000404X

Bech, K. 2001. Word order patterns in Old and Middle English: A syntactic and pragmatic study. Unpublished Ph.D. dissertation: University of Bergen.

Bech, K. 2017. Old truths, new corpora: Revisiting the word order of conjunct clauses in Old English. English Language and Linguistics 21(1). 1-25. https://doi.org/10.1017/S1360674315000465

Brown, W.H. 1969. Method and style in the Old English "Pastoral Care". The Journal of English and Germanic Philology 68(4). 666-684.

Cichosz, A. 2017. Verb-initial main clauses in Bede: A translation effect? In A. Kijak, J. Nykiel \& A.M. Łęcki (eds.), Current developments in English historical linguistics, 68-89. Katowice: Wydawnictwo Uniwersytetu Śląskiego.

Cichosz, A., J. Gaszewski \& P. Pęzik. 2016. Element order in Old English and Old High German translations. Amsterdam: Benjamins. https://doi.org/10.1075/nss.28

Devine, A.M. \& L. D. Stephens. 2006. Latin word order. Structured meaning and information. New York: Oxford University Press. https://doi.org/10.1093/acprof:0so/9780195181685.001.0001 
Fischer, O., A. van Kemenade, W. Koopman \& W. van der Wurff. 20oo. The syntax of early English. Cambridge: Cambridge University Press.

Fuß, E. \& C. Trips. 2002. Variation and change in Old and Middle English: On the validity of the Double Base Hypothesis. Journal of Comparative Germanic Linguistics 4. 171-224. https://doi.org/10.1023/A:1016588502117

Haeberli, E. 2002. Observations on the loss of verb second in the history of English. In C.J.W. Zwart \& W. Abraham (eds.), Studies in comparative Germanic syntax, 245-272. Amsterdam: Benjamins. https://doi.org/10.1075/la.53.15hae

Haeberli, E. \& S. Pintzuk. 2012. Revisiting verb (projection) raising in Old English. In D. Jonas, J. Whitman \& A. Garret (eds.), Grammatical change: Origins, nature, outcomes, 219-238. Oxford: Oxford University Press.

Kemenade, A. van. 1987. Syntactic case and morphological case in the history of English. Dordrecht: Foris. https://doi.org/10.1515/9783110882308

Koopman, W. 1995. Verb-final main clauses in Old English prose. Studia Neophilologica 67(2). 129-144. https://doi.org/10.1080/00393279508588156

Lemke, A. 2015. The Old English translation of Bede's Historia Ecclesiastica Gentis Anglorum in its historical and cultural context. Göttingen: Georg-August-University. https://doi.org/10.17875/gup2015-787

Mitchell, B. 1985. Old English syntax. Oxford: Clarendon. https://doi.org/10.1093/acprof:0so/9780198119357.001.0001

Ohkado, M. 200o. Verb first constructions in Old English, with special reference to Bede's Ecclesiastical history of the English people, 263-278. In M. Amano \& H. Nakano (eds.), Synchronic and diachronic studies on language: A festschrift for Dr. Hirozo Nakano. Nagoya: Nagoya University.

Pintzuk, S. 1996. Old English verb-complement word order and the change from OV to VO. York Papers in Linguistics 17. 241-264.

Pintzuk, S. 1999. Phrase structures in competition: Variation and change in Old English word order. New York: Garland.

Pintzuk, S. 2005. Arguments against a universal base: evidence from Old English. English Language and Linguistics 9(1). 115-38. https://doi.org/10.1017/S1360674305001565

Pintzuk, S. \& E. Haeberli. 2008. Structural variation in Old English root clauses. Language Variation and Change 20(3).367-407. https://doi.org/10.1017/S095439450800015X

Plummer, Ch. (ed.). 1896. Venerabilis Beadae, Historiam Ecclesiasticam Gentis Anglorum. Oxford: Oxford University Press. (available online at https://www.thelatinlibrary.com /bede.html)

Randall, B., A. Kroch \& A. Taylor. 2005-2013. CorpusSearch 2. (available online at http:// corpussearch.sourceforge.net/CS.html).

Ringe, D. \& A. Taylor. 2015. The development of Old English. Oxford: Oxford University Press.

Rowley, S. 2015. The long ninth century and the prose of King Alfred's reign. Oxford Handbooks Online. (Retrieved 9 Apr. 2020, from https://www.oxfordhandbooks.com /view/10.1093/oxfordhb/9780199935338.001.0001/oxfordhb-9780199935338-e-53)

Taylor, A. 2008. Contact effects of translation: distinguishing two kinds of influence in Old English. Language Variation and Change 20(3). 341-365. https://doi.org/10.1017/So954394508000100

Taylor, A., A. Warner, S. Pintzuk \& F. Beths. 2003. The York-Toronto-Helsinki Parsed Corpus of Old English Prose (YCOE). Department of Linguistics, University of York. Oxford Text Archive. (available online at http://www-users.york.ac.uk/ lang22/YcoeHome1.htm) 
Traugott, E. C. 1972. A history of English syntax. New York: Holt, Rinehart and Winston. Traugott, E. 1992. Syntax. In R.M. Hogg (ed.), The Cambridge history of the English language, vol. 1: The beginnings to 1066, 168-289. Cambridge: Cambridge University Press. https://doi.org/10.1017/CHOL9780521264747.005

Wallis, C. 2013. The Old English Bede: Transmission and textual history in Anglo-Saxon manuscripts. Unpublished Ph.D. dissertation: University of Sheffield.

Zimmermann, R. 2017. Formal and quantitative approaches to the study of syntactic change: Three case studies from the history of English. Unpublished Ph.D. dissertation: University of Geneva.

\section{Appendix}

\section{Verb definition file}

finite_verb:

${ }^{\star} \mathrm{VBPI}\left|{ }^{\star} \mathrm{VBDI}\right|{ }^{\star} \mathrm{VBP}\left|{ }^{\star} \mathrm{VBD}\right|{ }^{\star} \mathrm{BEPI}\left|{ }^{\star} \mathrm{BEDI}\right|{ }^{\star} \mathrm{BED}\left|{ }^{\star} \mathrm{BEP}\right|{ }^{\star} \mathrm{HVPI}\left|{ }^{\star} \mathrm{HVDI}\right|{ }^{\star} \mathrm{HVP}\left|{ }^{\star} \mathrm{HVD}\right|$

${ }^{\star} \mathrm{AXPI}\left|{ }^{\star} \mathrm{AXDI}\right|{ }^{\star} \mathrm{AXP}\left|{ }^{\star} \mathrm{AXD}\right|{ }^{\star} \mathrm{MDPI}\left|{ }^{\star} \mathrm{MDDI}\right|{ }^{\star} \mathrm{MDP} \mid{ }^{\star} \mathrm{MDD}$

\section{Query 1}

node: IP-MAT*

query: ((IP-MAT* iDoms finite_verb)

AND (IP-MAT* iDomsNumber $\left.1{ }^{\star} \mathrm{CONJ}{ }^{\star}\right)$ )

\section{Query 2}

node: IP-MAT*

query: ((IP-MAT* iDomsLast finite_verb)

AND (IP-MAT ${ }^{\star}$ iDomsNumber $\left.1{ }^{\star} \mathrm{CONJ}^{\star}\right)$ )

\section{Query 3}

node: IP-MAT*

add_to_ignore: NEG

query: ((IP-MAT* iDomsNumber $\left.1^{\star} \mathrm{CONJ}^{\star}\right)$

AND (IP-MAT* iDomsLast finite_verb)

AND (IP-MAT* iDoms NP-NOM ${ }^{\star}$ )

AND (NP-NOM* iDoms! $\left.\right|^{\star}$ con $\left.\right|^{*}||^{\star}$ pro $\left.\left.\left.\right|^{*}||^{\star} \exp \right|^{*}\right)$

AND (NP-NOM* iPrecedes! finite_verb)

AND (IP-MAT* iDoms ADV* ${ }^{\star} \mathrm{ADJ}^{\star}\left|\mathrm{PP}{ }^{\star}\right| \mathrm{BAG}|\mathrm{BEN}| \mathrm{BE}|\mathrm{RP}+\mathrm{BE}| \mathrm{HAG}|\mathrm{HVN}| \mathrm{HV} \mid$

$\left.\left.\mathrm{RP}+\mathrm{HV}|\mathrm{AXG}| \mathrm{AX}|\mathrm{VAG}| \mathrm{VBN}|\mathrm{VB}| \mathrm{RP}+\mathrm{VB}|\mathrm{MD}| \mathrm{NP}-\mathrm{DAT}{ }^{\star} \mid \mathrm{NP}-\mathrm{ACC}^{\star}\right)\right)$

\section{Query 4}

node: IP-MAT*

query: ((IP-MAT ${ }^{\star}$ iDomsNumber $\left.1{ }^{\star} \mathrm{CONJ}^{\star}\right)$

AND (IP-MAT* iDoms finite_verb)

AND (IP-MAT* iDoms BAG|BEN|BE $|\mathrm{RP}+\mathrm{BE}| \mathrm{HAG}|\mathrm{HVN}| \mathrm{HV}|\mathrm{RP}+\mathrm{HV}| \mathrm{AXG}|\mathrm{AX}| \mathrm{VAG} \mid$ $\mathrm{VBN}|\mathrm{VB}| \mathrm{RP}+\mathrm{VB} \mid \mathrm{MD}))$ 


\section{Query 5}

node: IP-MAT*

query: ((IP-MAT ${ }^{\star}$ iDomsNumber $\left.1{ }^{\star} \mathrm{CONJ}^{\star}\right)$

AND (IP-MAT* iDoms finite_verb)

AND (IP-MAT* iDoms BAG $|\mathrm{BEN}| \mathrm{BE}|\mathrm{RP}+\mathrm{BE}| \mathrm{HAG}|\mathrm{HVN}| \mathrm{HV}|\mathrm{RP}+\mathrm{HV}| \mathrm{AXG}|\mathrm{AX}|$ $\mathrm{VAG}|\mathrm{VBN}| \mathrm{VB}|\mathrm{RP}+\mathrm{VB}| \mathrm{MD})$

AND (BAG|BEN|BE $|\mathrm{RP}+\mathrm{BE}| \mathrm{HAG}|\mathrm{HVN}| \mathrm{HV}|\mathrm{RP}+\mathrm{HV}| \mathrm{AXG}|\mathrm{AX}| \mathrm{VAG}|\mathrm{VBN}| \mathrm{VB} \mid$

$\mathrm{RP}+\mathrm{VB} \mid \mathrm{MD}$ iPrecedes finite_verb))

\section{Query 6}

node: IP-MAT*

query: ((IP-MAT* iDoms finite_verb)

AND (IP-MAT ${ }^{\star}$ iDomsNumber $\left.1 !{ }^{\star} \mathrm{CONJ}^{\star}\right)$ )

\section{Query 7}

node: IP-MAT*

query: ((IP-MAT* ${ }^{\star}$ DomsLast finite_verb)

AND (IP-MAT* iDomsNumber $\left.1 !{ }^{\star} \mathrm{CONJ}^{\star}\right)$ )

\section{Query 8}

node: IP-MAT*

add_to_ignore: NEG

query: ((IP-MAT* iDomsNumber $\left.1 !{ }^{\star} \mathrm{CONJ}^{\star}\right)$

AND (IP-MAT* iDomsLast finite_verb)

AND (IP-MAT* iDoms NP-NOM ${ }^{\star}$ )

AND (NP-NOM* iDoms! $\left.\right|^{\star}$ con $\left.\right|^{\star}||^{\star}$ pro $\left.\left.\left.\right|^{\star}||^{\star} \exp \right|^{\star}\right)$

AND (NP-NOM* iPrecedes! finite_verb)

AND (IP-MAT* ${ }^{\star}$ iDoms ADV*|ADJ ${ }^{\star}\left|\mathrm{PP}^{\star}\right| \mathrm{BAG}|\mathrm{BEN}| \mathrm{BE}|\mathrm{RP}+\mathrm{BE}| \mathrm{HAG}|\mathrm{HVN}| \mathrm{HV} \mid$

$\mathrm{RP}+\mathrm{HV}|\mathrm{AXG}| \mathrm{AX}|\mathrm{VAG}| \mathrm{VBN}|\mathrm{VB}| \mathrm{RP}+\mathrm{VB}|\mathrm{MD}| \mathrm{NP}-\mathrm{DAT}^{\star}\left(\mathrm{NP}-\mathrm{ACC}^{\star}\right)$ )

\section{Query 9}

node: IP-MAT*

query: ((IP-MAT* iDomsNumber $\left.1 !^{\star} \mathrm{CONJ}^{\star}\right)$

AND (IP-MAT* iDoms finite_verb)

AND (IP-MAT* iDoms BAG $|\mathrm{BEN}| \mathrm{BE}|\mathrm{RP}+\mathrm{BE}| \mathrm{HAG}|\mathrm{HVN}| \mathrm{HV}|\mathrm{RP}+\mathrm{HV}| \mathrm{AXG}|\mathrm{AX}|$

$\mathrm{VAG}|\mathrm{VBN}| \mathrm{VB}|\mathrm{RP}+\mathrm{VB}| \mathrm{MD}))$

\section{Query 10}

node: IP-MAT*

query: ((IP-MAT ${ }^{\star}$ iDomsNumber $\left.1 !^{\star} \mathrm{CONJ}^{\star}\right)$

AND (IP-MAT* iDoms finite_verb)

AND (IP-MAT* iDoms BAG|BEN|BE|RP+BE $\mid$ HAG $|\mathrm{HVN}| \mathrm{HV}|\mathrm{RP}+\mathrm{HV}| \mathrm{AXG} \mid$

AX|VAG|VBN|VB|RP+VB|MD)

AND (BAG $|\mathrm{BEN}| \mathrm{BE}|\mathrm{RP}+\mathrm{BE}| \mathrm{HAG}|\mathrm{HVN}| \mathrm{HV}|\mathrm{RP}+\mathrm{HV}| \mathrm{AXG}|\mathrm{AX}| \mathrm{VAG}|\mathrm{VBN}| \mathrm{VB} \mid$

$\mathrm{RP}+\mathrm{VB} \mid \mathrm{MD}$ iPrecedes finite_verb)) 


\title{
Query 11
}

node: IP-SUB ${ }^{\star}$

query: (IP-SUB ${ }^{\star}$ iDoms finite_verb)

\section{Query 12}

node: IP-SUB ${ }^{\star}$

query: (IP-SUB ${ }^{\star}$ iDomsLast finite_verb)

\section{Query 13}

node: IP-SUB ${ }^{\star}$

add_to_ignore: NEG

query: ((IP-SUB ${ }^{\star}$ iDomsLast finite_verb)

AND (IP-SUB ${ }^{\star}$ iDoms NP-NOM ${ }^{\star}$ )

AND (NP-NOM* iDoms! $\left.\right|^{\star}$ con $\backslash^{\star}||^{\star}$ pro $\backslash^{\star}||^{\star}$ exp $\left.\backslash^{\star}\right)$

AND (NP-NOM* iPrecedes! finite_verb)

AND (IP-SUB ${ }^{\star}$ iDoms ADV ${ }^{\star}\left|\mathrm{ADJ}^{\star}\right| \mathrm{PP}^{\star}|\mathrm{BAG}| \mathrm{BEN}|\mathrm{BE}| \mathrm{RP}+\mathrm{BE}|\mathrm{HAG}| \mathrm{HVN}|\mathrm{HV}|$

$\left.\mathrm{RP}+\mathrm{HV}|\mathrm{AXG}| \mathrm{AX}|\mathrm{VAG}| \mathrm{VBN}|\mathrm{VB}| \mathrm{RP}+\mathrm{VB}|\mathrm{MD}| \mathrm{NP}-\mathrm{DAT}^{\star} \mid \mathrm{NP}-\mathrm{ACC}^{\star}\right)$ )

\section{Query 14}

node: IP-SUB ${ }^{\star}$

query: ((IP-SUB* iDoms finite_verb)

AND (IP-SUB* iDoms BAG|BEN|BE $|\mathrm{RP}+\mathrm{BE}| \mathrm{HAG}|\mathrm{HVN}| \mathrm{HV}|\mathrm{RP}+\mathrm{HV}| \mathrm{AXG} \mid$ $\mathrm{AX}|\mathrm{VAG}| \mathrm{VBN}|\mathrm{VB}| \mathrm{RP}+\mathrm{VB} \mid \mathrm{MD})$ )

\section{Query 15}

node: IP-SUB ${ }^{\star}$

query: ((IP-SUB* iDoms finite_verb)

AND (IP-SUB* iDoms BAG|BEN|BE $|\mathrm{RP}+\mathrm{BE}| \mathrm{HAG}|\mathrm{HVN}| \mathrm{HV}|\mathrm{RP}+\mathrm{HV}| \mathrm{AXG} \mid$

AX|VAG|VBN|VB|RP+VB|MD)

AND (BAG $|\mathrm{BEN}| \mathrm{BE}|\mathrm{RP}+\mathrm{BE}| \mathrm{HAG}|\mathrm{HVN}| \mathrm{HV}|\mathrm{RP}+\mathrm{HV}| \mathrm{AXG}|\mathrm{AX}| \mathrm{VAG}|\mathrm{VBN}| \mathrm{VB} \mid$

$\mathrm{RP}+\mathrm{VB} \mid \mathrm{MD}$ iPrecedes finite_verb))

\section{Address for correspondence}

\author{
Anna Cichosz \\ Institute of English Studies \\ University of Łódź \\ ul. Pomorska 171/173 \\ 90-236 Łódź \\ Poland \\ anna.cichosz@uni.lodz.pl \\ (iD) https://orcid.org/oooo-00o2-4095-5632
}

